\title{
Minilaparoscopic ovariohysterectomy in healthy cats
}

\author{
Thaíse Lawall ${ }^{\text {* }}$ Carlos Afonso de Castro Beck ${ }^{1}$ \\ Luciana Branquinho Queiroga ${ }^{1}$ Fabiane Reginatto dos Santos ${ }^{1}$
}

${ }^{1}$ Universidade Federal do Rio Grande do Sul (UFRGS), 91540-000, Porto Alegre, RS, Brasil. E-mail: tl.medvet@gmail.com. ${ }^{*}$ Corresponding author.

\begin{abstract}
The purpose of this study was to investigate the feasibility of minilaparoscopic (MINI) ovariohysterectomy (OHE) in healthy cats using three portals, one of 5 millimeters $(\mathrm{mm})$ in diameter and two of $3 \mathrm{~mm}$ diameter, along with bipolar diathermy. Technical difficulty, feasibility of MINI access, use of bipolar diathermy, surgery time, need for enlargement of incisions, trans- and post-operative complications and rate of conversion to open surgery were assessed. One out of 15 animals required incision enlargement, and one animal required conversion to celiotomy. The main postoperative complication observed was subcutaneous emphysema (46.7\%). In conclusion, MINI OHE is feasible in healthy cats.

Key words: endosurgery, spay, feline.
\end{abstract}

Ovariohisterectomia minilaparoscópica em gatas hígidas

RESUMO: O presente estudo objetivou descrever e avaliar a técnica de ovariohisterectomia (OVH) pelo acesso minilaparoscópico (MINI) quanto à viabilidade de execução do procedimento em gatas hígidas com uso de três portais: um de 5 milímetros (mm) combinado a outros dois portais de $3 \mathrm{~mm}$ de diâmetro e diatermia bipolar. Foram avaliadas as dificuldades relacionadas à técnica, o método hemostático, o tempo cirúrgico, a necessidade de ampliação das incisões, as complicações trans e pós-operatórias e, a taxa de conversão à cirurgia aberta. Dos 15 animais operados, um necessitou ampliação de uma das incisões e um paciente necessitou conversão à celiotomia. A complicação pósoperatória de maior ocorrência foi o enfisema subcutâneo (46,7\%). Conclui-se que a OVH por MINI em felinas hígidas é factível.

Palavras-chave: videocirurgia, esterilização, felina.

\section{INTRODUCTION}

Laparoscopy is a surgical technique under development in veterinary medicine (BECK et al., 2004). It is used both for elective and therapeutic surgery (HEDLUND, 2005) and for diagnostic purposes (BRUN et al., 2000) on the female reproductive system (SCHIOCHET et al., 2009), male reproductive system (BRUN \& BECK, 1999) and different organs (BECK et al., 2004).

Ovariohysterectomy (OHE) is a frequently performed surgical procedure (MAYHEW \& BROWN, 2007), especially for elective sterilization (BECK et al., 2004). Ovariohysterectomy is a an effective method for the sterilization of female cats, as well as for ovariectomy, without the inconveniences of uterine disease sometimes related to ovariectomy (LOPES, 2008). Several laparoscopic approaches for OHE have been described, including approaches through a single portal (LESS) (SILVA et al., 2011), two portals (FERREIRA et al., 2011), three portals (SCHIOCHET et al., 2009), and four portals (MALM et al., 2004). However, there are no reports of the minilaparoscopic (MINI) approach (KIM et al., 2011).

MINI, a logical advancement of minimally invasive surgery (MANAZZA et al., 2001; CARVALHO et al., 2013), stands out as it allows delicate and precise movements with maintenance of proper triangulation (CARVALHO et al., 2011). Smaller incisions are created with this approach, which results in less trauma to the abdominal wall (CARVALHO et al., 2011), thereby potentially 
reducing the parietal injury volume, the total area of tension at the incision and somatic pain (BLINMAN, 2010). Some of the advantages of this approach include increased precision, improved ergonomics, and enhanced vision and dexterity without a significant increase in operating time (CARVALHO et al., 2011).

In medicine, MINI has been evaluated since the 1990s, and it has been gradually introduced (AGRESTA \& BEDIN, 2012). In veterinary medicine, studies of the applicability of this technique are still scarce. The goal of this study was to describe and assess the use of the MINI technique for OHE in healthy cats.

\section{MATERIALS AND METHODS}

The 15 cats used in this study were routine patients at the Universidade Federal do Rio Grande do Sul Veterinary Hospital. The criteria for inclusion in this study were as follows: clinically healthy female; body weight of up to $5 \mathrm{~kg}$; complete blood count, creatinine and alanine aminotransferase levels within the normal reference ranges for the species; and no indication of pregnancy or uterine disorder on abdominal ultrasound.

Animals were fasted for 12 hours and were not allowed water for 2 hours prior to surgery. Meperidine $\left(5 \mathrm{mgkg}^{-1}\right)$ was administered intramuscularly as a pre-anesthetic drug. General anesthesia was induced by intravenous administration of $4 \mathrm{mgkg}^{-1}$ propofol, and maintenance of anesthesia was achieved with isoflurane in $100 \%$ oxygen, delivered via universal vaporizer, in an open circuit with assisted respiration. All animals received prophylactic antibiotic treatment with $20 \mathrm{mgkg}^{-1}$ ampicillin administered intravenously. All animals underwent urethral catheterization to empty the bladder.

To perform the surgical procedure, the animals were positioned in dorsal recumbency, with the head distal to the video monitor and the caudal portion of the body proximal to the monitor. The surgeon remained in front of the animal's head and in front of the video monitor through out the procedure (Figure 1A).

Based on the umbilical scar, a distance of nearly 4 to 5 centimeters $(\mathrm{cm})$ was established cranially where the first incision in the ventral midline was created, which was approximately $5 \mathrm{~mm}$ in length and involved the skin, subcutaneous tissue and linea alba. The first trocar, which was $5 \mathrm{~mm}$ in diameter $(\varnothing)$ and short, was inserted through this incision using an open technique. Pneumoperitoneum was obtained using $\mathrm{CO}_{2}$ and an electronic insufflator at a flow rate of $2.5 \mathrm{~L} / \mathrm{min}^{-1}$, reaching $11 \mathrm{mmHg}$ of pressure. Then, a rigid endoscope with a vision angle of $0^{\circ}$ and $4 \mathrm{~mm} \varnothing$, attached to a microcamera with an image processor and cold light source was introduced.

The laparoscopic procedure began with inspection of the abdominal cavity and the recording of any alterations. Then, the remaining trocars were placed (two of $3 \mathrm{~mm} \varnothing$ ); the second trocar was longer and was inserted into the right side of the abdomen (B), and the third trocar was shorter and was inserted into the left side (C) (Figure 1B and 1C). They were inserted at a distance of approximately 4 to $5 \mathrm{~cm}$ lateral and caudal to the initial trocar using a close technique under laparoscopic view.

After guided introduction of the instruments into the abdominal cavity, the uterine body was seized and suspended at the bifurcation area. On both sides of the uterine body, cranial to the cervix in the mesometrial area, a window was created lateral to the uterine vessels for adequate isolation and better positioning of the MINI bipolar electrocautery clamp, with the intensity set to 15 watts. Then, both the uterine vessels and uterine body were immediately electrocoagulated at three locations approximately $0,2 \mathrm{~cm}$ apart from each other. A transection was made between the second and third electrocoagulation sites using Metzenbaum scissors, leaving the stump. If no uterine horn segments or uterine bleeding was observed, then this surgical phase was concluded.

The right uterine horn was established in suspension traction with a Reddick-Olsen clamp until the right ovary was identified. The ovary was grasped by the ovarian proper ligament, which was subjected to caudal and dorsal traction to expose the ovarian pedicle. Next, a window was created in the mesovarium, on both sides of the ovarian pedicle, topper form electrocoagulation. Electrocoagulation and transaction of the ovarian pedicle and ovarian suspensory ligament were performed using the exact same technique as that described for electrocoagulation of the uterine vessels. For the contralateral ovary, the sequence of maneuvers was exactly the same. All procedures followed the same sequence and were performed by the same surgeon.

After completion of the OHE procedure, removal of tissues as a whole (ovaries and uterus) was performed through access " $\mathrm{B}$ ". Whenever necessary, the incision was enlarged in this same portal.

At the end of each procedure, the muscle fascia at the site of insertion of the first trocar (A) was sutured with absorbable multifilament suture 


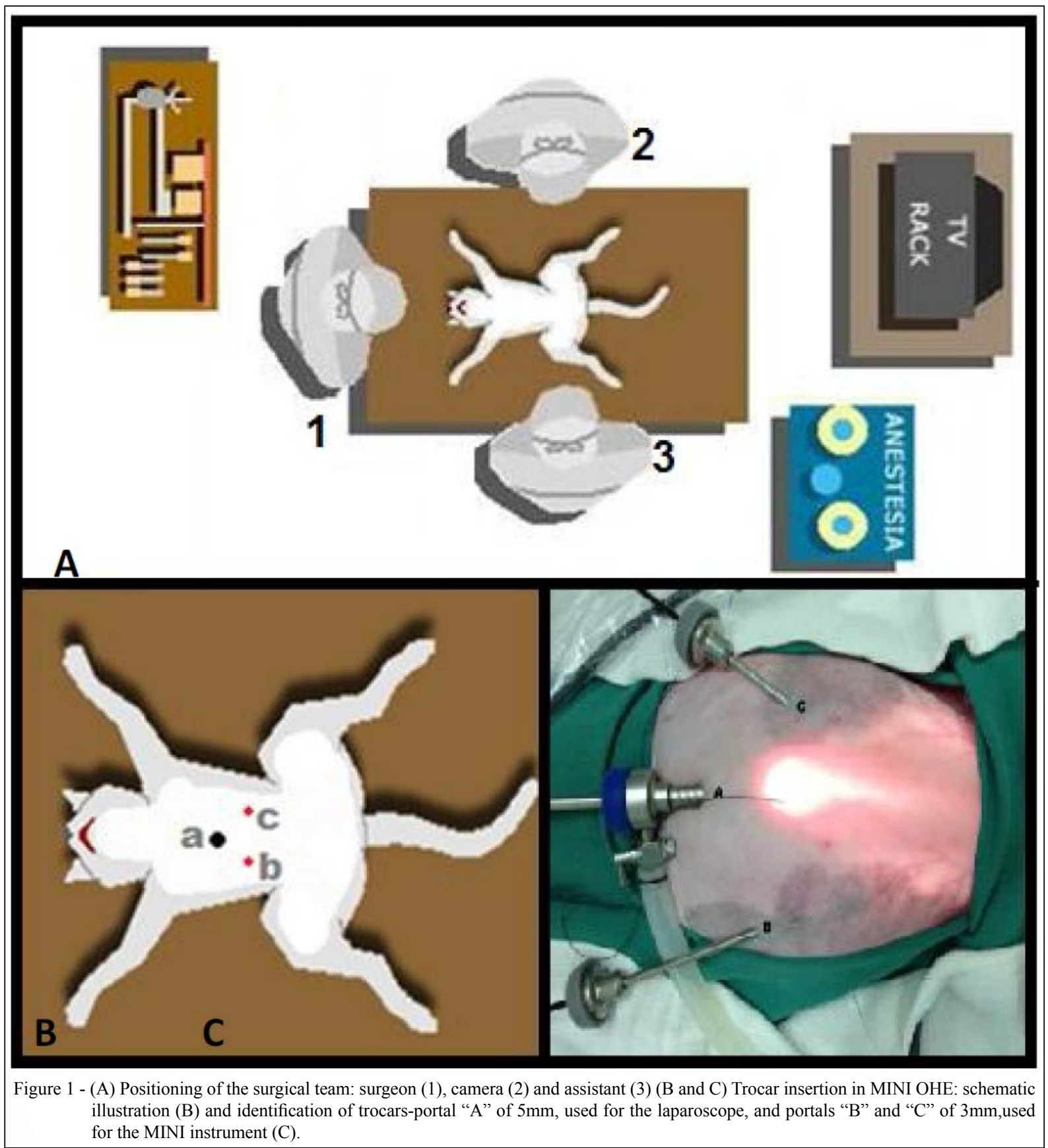

(polyglycolic acid 4-0) in a Sultan pattern, and the skin was sutured with non-absorbable monofilament suture (polyamide 3-0) in a simple isolated pattern. Only skin suturing was performed at the other trocar insertion sites (B and C).

The main goal of this study was to describe and assess application of the MINI technique for OHE with the use of three portals in healthy female cats, using optic with a $0^{\circ}$ viewing angle and $4 \mathrm{~mm}$ of $\varnothing$ combined with the use of two portals with $3 \mathrm{~mm}$ of $\varnothing$. The following aspects were also evaluated: access viability, technical difficulty, the use of bipolar diathermy, surgery time, the conversion rate to open surgery, the necessity of enlarging the incision for visceral removal, and post- and transsurgical complications.

Ciência Rural, v.47, n.2, 2017. 


\section{RESULTS AND DISCUSSION}

Some divergences about the definition of the MINI technique exist among reports in the literature (MANAZZA et al., 2001; AGRESTA \& BEDIN, 2012; KRPATA \& PONSKY, 2013). However, this study was conducted based on the assertion of CARVALHO et al. (2011) that the MINI technique uses one 5 or $10 \mathrm{~mm}$ portal, which must be in the umbilical position, while the other portals must be $3 \mathrm{~mm}$ or less.

In medicine, CARVALHO et al. (2012) have used an optic of $10 \mathrm{~mm} \varnothing$ in three different techniques for inguinal hernia repair through MINI. Further, LEGGETT et al. (2001) performed cholecystectomy using the MINI technique, with a $5 \mathrm{~mm}$ optic in the umbilical portal, and reported that enlargement of the incision for gallbladder removal was necessary in less than $20 \%$ of cases. These results supported the reliability of the MINI technique using any instrument with less than $5 \mathrm{~mm} \varnothing$ (MANAZZA et al., 2001).

CARVALHO \& CAVAZZOLA (2010) have observed that creation of several small incisions causes less injury than creation of a single larger incision, even if the incisions have equal total lengths when added together. This conclusion was based on a cylindrical geometric model used to calculate the injury volumes of different sizes of laparoscopic incisions.

Considering that a cylinder's volume (v) is calculated as $\mathrm{v}=\pi \cdot \mathrm{r}^{2} \cdot \mathrm{h}$ (where " $\mathrm{v}$ " is the injury volume in $\mathrm{mm}^{3}$, " $\pi$ " is a numerical constant with the value of 3.14, "r" as the radius, and " $h$ " is a constant representing the average value of the abdominal wall height (which is $7.125 \mathrm{~mm}$ in female cats (LAWALL, 2015), it was possible to deduce that the injury volume is directly and exponentially proportional to the radius of the incision. Furthermore, the greater the volume, the greater the injury and pain (CARVALHO \& CAVAZZOLA, 2010).

Application of this formula to veterinary surgical practice enabled the verification that MINI is advantageous compared with all other laparoscopic techniques used for $\mathrm{OHE}$ in female cats that required incisions in relation to the estimated volume of parietal injury.

Considering that three $5 \mathrm{~mm}$ portals are used in conventional laparoscopy, the estimated parietal injury is approximately of $419.46 \mathrm{~mm}^{3}$. In modified laparoscopy, which uses two $5 \mathrm{~mm}$ portals and one $3 \mathrm{~mm}$ portal, the estimated parietal injury is approximately of $329.97 \mathrm{~mm}^{3}$. In single port access, a $15 \mathrm{~mm}$ incision is created, and the estimated parietal injury is $1258.45 \mathrm{~mm}^{3}$. In video-assisted access, two $5 \mathrm{~mm}$ portals are used, and the estimated injury volume is $279.64 \mathrm{~mm}^{3}$, whereas the MINI technique uses two $3 \mathrm{~mm}$ portals and one $5 \mathrm{~mm}$ portal and has an estimated injury volume of $240.48 \mathrm{~mm}^{3}$. Therefore, the sum of the total length of incisions is not a determining factor for the extent of damage (LAWALL, 2015).

Each animal in this study was administered prophylactic ampicillin prior to surgery, considering that some of the laparoscopic instruments could not be sterilized by autoclaving, although they were subjected to high-level disinfection (SILVA et al., 2003) through immersion in peracetic acid.

During surgery, the laparoscope was inserted approximately $4-5 \mathrm{~cm}$ cranial to the umbilicus, as described by SCHIOCHET et al. (2009). However, MAYHEW \& BROWN (2007) have reported positioning of the laparoscope just below the umbilicus, which allows for good visualization of the abdominal organs. The laparoscope used and its proper positioning provided adequate visualization of anatomical structures, enabling execution of the proposed surgical technique. Although the use of a smaller scope results in reduced parietal injury due to the use of smaller trocars, the use of a 2 or $3 \mathrm{~mm}$ optic would considerably increase the cost of the procedure because the instruments are moderately durable and expensive; and these features not provide significant benefits to the technique (CARVALHO et al., 2009; CARVALHO et al., 2012).

Bipolar electrocautery enabled excellent coagulation of the tissues. Similar results have been described by SCHIOCHET et al. (2009) and BART et al. (2003) in comparisons to mono and bipolar electrocautery in laparoscopic ovariectomy. The power used in the present study was 15 watts; however, the indications vary at approximately 20 watts (FREEMAN \& HENDRINKSON, 1998).

To remove tissues resulting from $\mathrm{OHE}$, FREEMAN \& HENDRINKSON (1998) have suggested transferring the laparoscope to one of the lateral portals and removing the agglomerate under direct vision through the portal in which the optic is inserted. However, we did not modify the scope position in the present study. Ovaries and uterus were removed through the incision of the right lateral portal (portal B) under direct vision for all animals.

Only one of the 15 animals required enlargement of the portal " $\mathrm{B}$ " incision to remove the uterus, ovaries and adjacent tissues. MALM et al. (2004) reported the same requirement for two of 15 patients in their study. DAVIDSON et al. (2004) also mentioned this possibility and considered incision enlargement to be 
important. Tissue maceration is another option for organ removal (KOLATA \& FREEMAN, 1998). However, these procedures were not used in this study because one of the aims was to verify the actual feasibility of whole organ removal through the MINI approach.

Upon completion of the OHE procedure, the abdominal cavity was inspected under reduced abdominal pressure to identify eventual mild or unapparent bleeding sites during pneumoperitoneum (BRUN et al., 2000). Portals were removed under laparoscopic vision(FREEMAN \& HENDRINKSON, 1998), and the incisions were sutured after removal of the remaining $\mathrm{CO}_{2}$

Insertion sites of $5 \mathrm{~mm}$ must be sutured to prevent omental herniation (FREEMAN \& HENDRINKSON, 1998); therefore, the location corresponding to the scope portal was sutured. The other two lateral portals sites received only skin suturing as described by MANAZZA et al. (2001). Incisional hernia was not observed in any of the animals.

BRUNetal.(2000), DAVIDSONetal.(2004), and MALM at al. (2004) have reported hemorrhage as a trans-surgical complication. AZEVEDO (2011) has reported that vascular injures the most common cause of death in laparoscopic procedures. In our study, only one animal presented hemorrhage of the uterine vessels, which was probably due to insufficient hemostasis; this animal was subjected to new cauterization, which did not stop the bleeding. Thus, conversion to celiotomy was selected, as indicated by BRUN et al. (2000), corroborating the assertion of De LISLE et al. (1995), who reported that hemorrhage due to major injury requires immediate action, such as electrocoagulation or even conversion to laparotomy.

MANAZZA et al. (2001) have reported difficulties in achieving hemostasis using the MINI technique. The conversion of laparoscopic surgery due to hemorrhage has also been described in humans (FANFANI et al., 2012). In small animal laparoscopy, BUOTE et al. (2011) have reported a conversion rate of $21 \%$, which is different from that observed in this study $(6.7 \%)$.

Fewer postoperative complications were observed in this study compared with previous studies (DAVIDSON et al., 2004; MALM et al., 2005; MAYHEW \& BROWN, 2007; SCHIOCHET et al., 2009; MANASSERO et al., 2012). We observed subcutaneous emphysema in seven of the 15 animals in this study. The emphysema resolved in all of these animals within the first 12 post-operative hours. This complication probably occurred due to the leakage of $\mathrm{CO}_{2}$ gas around the trocars, as described by BRUN et al. (2000) and BECK et al. (2003).
Emphysema has been reported to occur during surgical procedures in clinical medicine (SAVASSI-ROCHA, 1995) and veterinary medicine (BECK et al., 2003), but it does not prevent continuation of the procedures (CAMPOS \& ROLL, 2003). In most cases, it resolves spontaneously through gas reabsorption without causing damage to the patient (DELISLE et al., 1995).

The animals in this study did not develop surgical wound complications, in contrast with the findings of MALM et al. (2005). However, in these previous studies (BRUN et al., 2000; MALM et al., 2004; MALM et al., 2005), trocars of $6 \mathrm{~mm}$ or larger were used.

The operative time, defined as the time from the beginning of the first incision to the last skin suture (COISMAN et al., 2014), was an average of 62 minutes, which is shorter than that reported by SCHIOCHET et al. (2009), who performed OHE on felines with three portals using the same hemostatic method. However, it is longer than that reported by FERREIRA et al. (2011), who used a technique with only two portals, characterized as a video-assisted or hybrid technique (MINAMI et al., 1997). DAVIDSON et al. (2004) have suggested that a maximum surgical time of 60 minutes is appropriate; this time is very close to the average time of the procedures in this study.

\section{CONCLUSION}

Based on the results of this study, use of the MINI approach for OHE in female cats is feasible and represents another option among the surgical techniques used for routine elective surgical sterilization.

\section{BIOETHICS AND BIOSSECURITY COMMITTEE APPROVAL}

Number 26161.

\section{ACKNOWLEDGEMENTS}

The authors thank Coordenação de Aperfeiçoamento de Pessoal de Nível Superior (CAPES) for the financial support.

\section{REFERENCES}

AGRESTA, F.; BEDIN, N. Is there still any role for minilaparoscopic cholecystectomy? A general surgeons last five years experience over 932 cases. Updates in Surgery, v.64, p.3136, 2012. doi: 10.1007/s13304-011-0123-2.

AZEVEDO, J.L.M.C. Establishing an artificial pneumoperitoneum for laparoscopic procedures. Brazilian Journal of Video Endoscopic Surgery, v.4, n.1, p.35-41, 2011. 
BART, E.B.J. et al. Monopolar versus bipolar eletrocoagulation in canine laparoscopic ovariectomy: A nonrandomized, prospective, clinical trial. Veterinary surgery, v.32, n.5, p.464-470, 2003. doi: $10.1053 /$ jvet.2003.50052.

BECK, C.A.C. et al. Rabbit cryptorchidectomy: experimental model to laparoscopic training. Ciência Rural, v.33, n.2, p.331-337, 2003. Available from: <http://www.scielo.br/scielo. php script $=$ sci_arttext\&pid $=$ S0103-84782003000200023\&lng $=$ pt\&nrm=iso $>$. Accessed: Jul. 08, 2014. doi: 10.1590/S010384782003000200023 .

BECK, C.A.C. et al. Ovariectomia em uma cadela com ovários remanescentes: relato de caso. Revista científica de Medicina Veterinária de Pequenos Animais de Estimação, v.2, n.5, p.1519, 2004.

BLINMAN, T. Incisions do not simply sum. Surgical Endoscopy, v.24, n.7, p.1746-1751, 2010. doi: 10.1007/s00464-009-0854-z.

BRUN, M.V.; BECK, C.A.C. Aplicações clínicas e experimentais da laparoscopia em cães - artigo de revisão. Revista da Faculdade de Zootecnia, Veterinária e Agronomia, v.5/6, n.1, p.123-135, 1999. Available from: <http://revistaseletronicas.pucrs.br/ojs/ index.php/fzva/article/view/1996/1500 > . Accessed: Oct. 30, 2014.

BRUN, M.V. et al, Ovariohisterectomia em caninos por cirurgia laparoscópica. Brazilian Journal of Veterinary Research and Animal Science, v.37,n.6, p.480-485, 2000. Available from: $<\mathrm{http}: / /$ www.revistas.usp.br/bjvras/article/view/5866/62558>. Accessed: Oct. 30, 2014. doi: 10.1590/S1413-95962000000600011.

BUOTE, N.J. et al. Conversion from diagnostic laparoscopy to laparotomy: risk factors and occurrence. Veterinary Surgery, v.40, p.106-114, 2011. doi: 10.1111/j.1532-950X.2010.00759.x.

CAMPOS, F.G.C.M.; ROLL, S. Complicações do acesso abdominal e do pneumoperitônio em cirurgialaparoscópica - causas, prevenção e tratamento. Revista Brasileira de Videocirurgia, v.1, p.21-28, 2003. Available from: <http://www.sobracil.org.br/ revista/rv010101/rbvc010101_021.pdf>. Accessed: Sept. 19, 2014.

CARVALHO, G.L.; CAVAZZOLA, L.T. Can mathematic formulas help us with our patients? Letter. Surgical Endoscopy, 2010. doi: 10.1007/s00464-010-1065-3.

CARVALHO, G.L. et al. Minilaparoscopic surgery - not just a pretty face! What can be found beyond the esthetics reasons? Journal of Laparoendoscopic and Advanced Surgical Techniques, v.23, n.x, p.1-4, 2013. doi: 10.1089/lap.2013.0147.

CARVALHO, G.L. et al. Minilaparoscopic technique for inguinal hernia repair combining transabdominal pre-peritoneal and totally extraperitoneal approaches. Journal of the Society of Laparoendoscopic Surgeons, v.16, p.569-575, 2012. doi: 10.429 3/108680812X13462882737096.

CARVALHO, G.L. et al. Needlescopic clipless cholecystectomy as an efficient, safe, and cost-effective alternative with diminutive scars. The first 1000 cases. Surgical Laparoscopy Endoscopy \& Percutaneous Technique, v.19, p.368-372, 2009. doi: 10.1097/ SLE.0b013e3181b7d3c7.

CARVALHO, G.L. et al. Renaissance of minilaparoscopy in the NOTES and single port era. Journal of the Society of Laparoendoscopic Surgeons, v.15, p.585-588, 2011.
Available from: <https://www.ncbi.nlm.nih.gov/pmc/articles/ PMC3340978/>. Accessed: Jul. 08, 2013. doi: 10.4293/10868081 $1 \mathrm{X} 13176785204832$.

COISMAN, J.G. et al. Comparison of surgical variables in cats undergoing single-incision laparoscopic ovariectomy using a ligasure or extracorporeal suture versus open ovariectomy. Veterinary Surgery, v.43, p.38-44, 2014. doi: 10.1111/j.1532950X.2013.12073.x.

DAVIDSON, B. et al. Comparison of laparoscopic ovariohysterectomy and ovariohysterectomy in dogs. Veterinary Surgery, v.33, p.62-69, 2004. doi: 10.1111/j.1532950X.2004.04003.x.

DE LISLE, N.P. et al. The team: nursing's perspective. In: ARREGUI, M.E. et al. Principles of Laparoscopic Surgery: Basic and Advances Techniques. New York: Springer-Verlag, 1995. p.91-100.

FANFANI, F. et al. Laparoscopic, minilaparoscopic and single-port hysterectomy: perioperative outcomes. Surgical Endoscopy, v.26, p.3592-3596, 2012. doi: 10.1007/s00464-012-2377-2.

FERREIRA, M.P. et al. Laparoscopic ovariohysterectomy in domestic cats: two portals technique. Acta Scientiae Veterinariae, v.39, n.4, p.997, 2011. Available from: <http://www.ufrgs.br/ actavet/39-4/PUB\%20997.pdf>. Accessed: Nov. 29, 2013.

FREEMAN, L.J. Introduction. In .Veterinary Endosurgery. Missouri: Mosby, 1998. p.xi.

FREEMAN, L.J.; HENDRICKSON, D.A. Applications of endosurgery: minimally invasive surgery of the reproductive system. In: FREEMAN, L.J. Veterinary Endosurgery. Missouri: Mosby, 1998. p.205-225.

HEDLUND, C.S. Cirurgia dos sistemas reprodutivo e genital. In: FOSSUM, T.W. Cirurgia de Pequenos Animais. 2ed. São Paulo: Roca, 2005. p.610-646.

KIM, S.Y. et al. Feasibility of single-portal access laparoscopic ovariectomy in 17 cats. Veterinary Record, v.169, n.7, p.169-179, 2011. doi: 10.1136/vr.d4293.

KOLATA, R.J.; FREEMAN, L.J. Access, port placement, and basic endosurgical skills. In: FREEMAN, L.J. Veterinary Endosurgery. Missouri: Mosby, 1998. p.44-60.

KRPATA, D.M.; PONSKY, T.A. Needlescopic surgery: what's in the toolbox? Surgical Endoscopy, v.27, p.1040-1044, 2013. doi: $10.1007 / \mathrm{s} 00464-012-2548-1$.

LAWALL, T. Ovariohisterectomia minilaparoscópica em gatas hígidas. 2015. 115f. Dissertação. Mestrado em Cirurgia Animal. Curso de Pós-graduação em MedicinaVeterinária, Universidade Federal do Rio Grande do Sul, Porto Alegre, RS.

LEGGETT, P.L. et al. Cosmetic minilaparoscopic cholecystectomy. Surgical Endoscopy, v.15, p.1229-1231, 2001. doi: 10.1007/ s004640041018.

LOPES, M.D. Terapêutica do sistema reprodutor: terapêutica do sistema reprodutor empequenos animais. In.: ANDRADE, S.F. Manual de Terapêutica Veterinária. 3. ed. SãoPaulo: Roca, 2008.p.377-395. 
MALM, C. et al. Ovariohisterectomia: estudo experimental comparativo entre as abordagens laparoscópica e aberta na espécie canina. Intra-operatório-I. Arquivo Brasileiro de Medicina Veterinária e Zootecnia, v.56, n.4, p.457-466, 2004. Available from: <http://dx.doi.org/10.1590/S0102-09352004000400006 > Accessed: Dec. 18, 2013

MALM, C. et al. Ovariohisterectomia: estudo experimental comparativo entre as abordagens laparoscópica e aberta na espécie canina. II - Evolução clínica pós-operatória. Arquivo Brasileiro de Medicina Veterinária e Zootecnia, v.57, suppl.2, p.162172, 2005. Available from: <http://dx.doi.org/10.1590/S01020935200500080006>. Accessed: Nov. 28, 2014.

MAMAZZA, J. et al. Needlescopic surgery: a logical evolution from conventional laparoscopic surgery. Surgical Endoscopy, v.15, n.10, p.1208-1212, 2001. doi: 10.1007/s004640080024.

MANASSERO, M. et al. Laparoscopic ovariectomy in dogs using a single-port multiple-access device. Veterinary Record, v.171, n.3, p.69, 2012. doi: 10.1136/vr.100060.

MAYHEW, P.D.; BROWN, D.C. Comparison of three techniques for ovarian pedicle hemostasis during laparoscopic-assisted ovariohysterectomy. Veterinary Surgery, v.36, n.6, p.541-547, 2007. doi: 10.1111/j.1532-950X.2007.00280.x.
MINAMI, S. et al. Successful laparoscopy assisted ovariohysterectomy in two dogs with pyometra. Journal of Veterinary Medical Science, v.59, n.9, p.845-847, 1997. Available from: <https://www.jstage.jst.go.jp/article/jvms/59/9/59_9_845/ pdf>. Accessed: Jan. 16, 2015. doi: 10.1292/jvms.59.845.

SAVASSI-ROCHA, P.R. Colecistectomia. In.: COELHO, J.C.U. et al. Complicações da videocirurgia: da profilaxia ao tratamento. Rio de Janeiro: MEDSI, 1995. p.183-241.

SCHIOCHET, F. et al. Ovariohisterectomia laparoscópica em felinos hígidos: estudo comparativo de três métodos de hemostasia. Arquivo Brasileiro de Medicina Veterinária e Zootecnia, v.61, n.2, p.369-377, 2009. Available from: <http://dx.doi.org/10.1590/ S0102-09352009000200013>. Accessed: Sept. 09, 2013.

SILVA, R.C.O. et al. O ethanol 70 na desinfecção de óticas na vídeolaparoscopia. Revista Brasileira de Videocirurgia, v.1, n.3, p.92-95, 2003. Available from: <http://www.sobracil.org.br/ revista/rv010103/rbvc010103_092.pdf>. Accessed: Aug. 16, 2014.

SILVA, M.A.M. et al. Ovariohisterectomia vídeo-assistida com único portal em cadelas: estudo retrospectivo de 20 casos. Ciência Rural, v.41, n.2, p.294-300. 2011. Available from: $<$ http://www.scielo.br/pdf/cr/v41n2/a871cr4012.pdf >. Accessed: May 23, 2013. 